\title{
The Impact of an ODI on the Development of Leadership, Employee Motivation and Employee Engagement towards Better Performance of Employees: A Case Study
}

Submitted 21/03/21, $1^{\text {st }}$ revision 15/04/21, $2^{\text {nd }}$ revision 30/04/21, accepted 20/05/21

\author{
Jonathan Chih Win Zaw Tun ${ }^{1}$, Papitchaya Wisankosol ${ }^{2}$
}

\begin{abstract}
:
Purpose: Leadership, Motivation and Employee Engagement has been a key essence of improving the performance of employee by means of job engagement, job satisfaction and individual performance towards achieving team performance. The organization, OV Logistics (Myanmar) Ltd, Singapore owned and managed, Logistics \& Freight Forwarding and Supply Chain Solutions service provider in Myanmar, with 81 employees had been selected to identify the focal challenges and in placed the action research. 4 variables had been identified.

Design/Methodology/Approach: This research included a mix method of study to collect the data by understanding the current challenges towards the object of this study upon completion of the quantitative data collection before and after the OD interventions, which was analyzed using paired t tests, Wilcoxon and Spearman Correlation.

Findings: The findings indicated a strong significant connection between leadership, motivation, employee engagement and better performance of employees. The findings had been presented to the management and employees of OV Logistics (Myanmar) Ltd, in which the connection and significance of Leadership, Motivation and Employee Engagement had been inter-connected each other as to have the better performance of employee.

Practical Implications: Despite the study gives the organization to consider further research on the area of "the management and internal organization conflict" and "changing organization behavior" toward the organizational achievement.

Originality/Value: The research contributes the conceptual framework, theoretical framework and action research framework in order meet the objectives of the study as well as contributing the guidelines for the organization for the next level of action plans to overcome the challenges in the competitive market.
\end{abstract}

Keywords: Leadership, Motivation, Employee engagement, Employee performance, Organization Development.

JEL codes:

Paper Type: Research Paper

\footnotetext{
${ }^{1}$ Assumption University, Thailand, chih.jonathan@gmail.com

${ }^{2}$ Associate Program Director, Doctor of Philosophy in Organization Development, Graduate School of Business and Advanced Technology Management, Assumption University,

Thailand, papitchayawsn@au.edu
} 


\section{Introduction}

Globalization is progressively connect all around the world. Even small countries and regions are link between North, South, East and West to meet the global economic to enhance. In the globalization period, goods and services are intense to compete in the market come into force emerging economies. Even the third countries regarded by international community, at preset become the competition in international market. Generally logistic and freight forwarding are a specific and execution of organization with operational complexity. Since 1950, logistic industry getting growth in all around the world. In the business industry, logistic and freight forwarding are a kind of intermediary management between exporter/importer, shipper and carrier. Freight forwarding, in others called "Non-Vessel Operating Common Carrier (NVOCC)" is a private organization or private company which arrange the cargoes and goods from manufacturer or customer to ship to destination.

According to Johnson and Wood's (Tilanus, 1997) propose that logistic have "five potential key factors" that describe as logistics, materials management, supply-chain management, inbound logistics and distribution. Logistics express the product material moving through in and out of firm. Material management define the movement of goods within a firm. Supply-Chain management is management and communication between one or more logistics firm. Inbound logistic is collecting the cargoes or goods from supplier or manufacturer.

Finally distribution define the moving goods from firm to customer. The effectiveness of moving goods decided by the transportation operation efficiency. In 1991, Logistics Management Council present that the logistics is part of the supply chain process plans, efficient controls, implements, effective forward and flow of reverse storage of goods and services to meet the point to point consumption on the customer requirements.

The objectives of this research are as follows:

- To examine the current situation leadership, employee motivation, employee engagement, and employee performance in OV Logistics (Myanmar) Ltd.

- To design and propose the Organization Development Interventions (ODIs) to develop leadership, employee motivation, and employee engagement in OV Logistics (Myanmar) Ltd.

- To determine the differences between the Pre and Post ODI on leadership, employee motivation, and employee engagement in OV Logistics (Myanmar) Ltd.

- To observe the influence of leadership, employee motivation, and employee engagement on employee performance.

- To observe the influence of leadership on employee motivation and employee motivation on employee engagement. 


\section{Literature Review}

Leadership to be able to exercise authority over the employee to do voluntarily, should be (Cribbin, 1981). Leadership is defined as an effective organizational strategy, influencing the organizational group by achieving objectives. Leadership is not for a specific position, which is complex in relation to the moral sense of relationship among the people, belief, responsibility, commitment, and impression and sharing of the right vision. Leadership is about influencing and directing one or more people to command the process to achieve goals using human resources.

Nowadays, many organizations are looking for ways to motivate employees for success, management, metaphors, and modernization for organizational functions in the organization (House et al., 1991; Jones and Olken, 2005). Motivation can lead to better performance rate of the organization. In the achievement of early theories, motivation is drive and action (Atkinson, 1957). Employee job involvement is a positive result of emotions that reflects the outcome of the work situation (Lock, 1976). In addition, job satisfaction traditionally differs from employee engagement. It is defined as a state of cognitive belief that reflects some level of mental identity with work (Kanungo, 1982). Many research studies suggested that employee engagement and job satisfaction is defined as a convertible concept. (Altarawneh and Albdour, 2014) suggested that employee engagement practices and organizational performance are increasingly important for policymakers and empirical researchers in terms of evidence-based work in order to achieve job satisfaction and significant performance in the organization.

Figure 1. Conceptual Framework of this Study

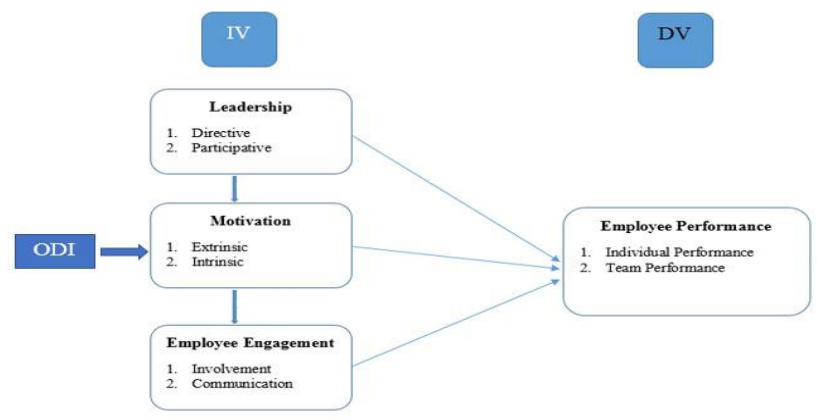

Source: Own study.

\section{Research Methodology}

\subsection{Data Analysis and Data Analysis Method}

The data analysis of this research study was used various methods to analysis the data with different instruments. The researcher used to analyze the qualitative data with 
Median, Mean, Interquartile Range, Wilcoxon Test, Spearman Correlation Coefficient and Improvement of Percentage because this research was based on non-parametric statistical. The researcher used non-parametric because this research have two group to compares the data.

Median and Interquartile Range: calculating the middle values of the total sequence data. Mean and St. Deviation: are calculating the average of total sequence data.

Wilcoxon Test: used to analyze comparison of the data between Pre ODI and Post ODI of manager and employee survey questionnaires.

Spearman Rank Correlation Coefficient: used to discover the relationship between Leadership, Motivation, Employee Engagement and Employee Performance.

Table 1. Demographic Profile of Respondents

\begin{tabular}{|c|c|c|c|}
\hline \multicolumn{4}{|l|}{ Gender } \\
\hline & Male & 45 & $56 \%$ \\
\hline & Female & 36 & $44 \%$ \\
\hline \multicolumn{4}{|l|}{ Position } \\
\hline & Manager & 22 & $27 \%$ \\
\hline & Employee & 59 & $73 \%$ \\
\hline \multicolumn{4}{|l|}{ Age } \\
\hline & less than 20 & 6 & $7 \%$ \\
\hline & $20-30$ & 31 & $38 \%$ \\
\hline & $31-40$ & 28 & $35 \%$ \\
\hline & $41-50$ & 15 & $19 \%$ \\
\hline & $51-60$ & 1 & $1 \%$ \\
\hline \multicolumn{4}{|l|}{ Income } \\
\hline & $100,000-500,000 \mathrm{MMK}$ & 42 & $52 \%$ \\
\hline & 500,000 - 1,000,000 MMK & 21 & $26 \%$ \\
\hline & $1,000,000-1,500,000 \mathrm{MMK}$ & 11 & $14 \%$ \\
\hline & $1,500,000-2,000,000 \mathrm{MMK}$ & 6 & $7 \%$ \\
\hline & Above $2,000,000 \mathrm{MMK}$ & 1 & $1 \%$ \\
\hline \multicolumn{4}{|c|}{ Education } \\
\hline & High School or below & 29 & $36 \%$ \\
\hline & Bachelor degree & 51 & $63 \%$ \\
\hline & Master degree & 1 & $1 \%$ \\
\hline \multicolumn{4}{|c|}{ Marital Status } \\
\hline & Single & 39 & $48 \%$ \\
\hline & Engaged & 3 & $4 \%$ \\
\hline & Married & 37 & $46 \%$ \\
\hline & Divorced & 1 & $1 \%$ \\
\hline & Widowed & 1 & $1 \%$ \\
\hline \multicolumn{4}{|c|}{ Nature of Job } \\
\hline & Temporary & 2 & $2 \%$ \\
\hline & Permanent & 79 & $98 \%$ \\
\hline
\end{tabular}

Source: Own study. 
The Impact of an ODI on the Development of Leadership, Employee Motivation 26 and Employee Engagement towards Better Performance of Employees: A Case Study

Table 2. Pre \& Post Median Improvement

\begin{tabular}{llllll}
\hline Variables & $\begin{array}{l}\text { PRE ODI } \\
\text { Median } \\
\text { (5 Point) }\end{array}$ & $\begin{array}{l}\text { POST } \\
\text { ODI Me- } \\
\text { dian } \\
\text { Point) }\end{array}$ & $\begin{array}{l}\text { PRE Inter- } \\
\text { quartile } \\
\text { Range }\end{array}$ & $\begin{array}{l}\text { POST Inter- } \\
\text { quartile } \\
\text { Range }\end{array}$ & $\begin{array}{l}\text { Median \% } \\
\text { Improve- } \\
\text { ment }\end{array}$ \\
\hline Directive Leadership & 3.00 & 4.00 & 1.00 & 1.00 & $33.33 \%$ \\
\hline Participative Leadership & 3.00 & 4.00 & 1.00 & 1.00 & $33.33 \%$ \\
\hline Extrinsic Motivation & 3.00 & 4.00 & 2.00 & 1.00 & $33.33 \%$ \\
\hline Intrinsic Motivation & 3.00 & 4.00 & 2.00 & 1.00 & $33.33 \%$ \\
\hline $\begin{array}{l}\text { Employee Engagement } \\
\text { Involvement }\end{array}$ & 3.00 & 4.00 & 1.00 & 1.00 & $33.33 \%$ \\
\hline $\begin{array}{l}\text { Employee Engagement } \\
\text { Communication }\end{array}$ & 3.00 & 3.00 & 1.00 & 1.00 & $0.00 \%$ \\
\hline $\begin{array}{l}\text { Employee Individual } \\
\text { Performance }\end{array}$ & 3.00 & 4.00 & 2.00 & 1.00 & $33.33 \%$ \\
\hline $\begin{array}{l}\text { Employee Team Perfor- } \\
\text { mance }\end{array}$ & 3.00 & 4.00 & 1.75 & 1.00 & $33.33 \%$ \\
\hline \begin{tabular}{lllll} 
Source: Own \\
\hline
\end{tabular} & & &
\end{tabular}

Source: Own study.

In Table 2 Pre and Post Median comparison we can see the ODI improvement of median value of variables except the employee engagement communication. Because there is time limitation in the ODI process, changing organizational behavior and human behavior cannot be done within the short period.

Table 3. Paired Samples T-Test of Directive Leadership: T-Test Outcome Q1-Q5

\begin{tabular}{llllllllc}
\hline \multicolumn{2}{l}{ Paired Samples Test } \\
\hline \multicolumn{10}{l}{ Paired Differences } \\
\hline
\end{tabular}

Source: Own study.

According to Table 3 above, the different significant scores for Q1 are without ODI $(\mathrm{M}=3.14, \mathrm{SD}=0.89)$ and $\mathrm{Q} 1$ with ODI $(\mathrm{M}=4.22, \mathrm{SD}=0.61), \mathrm{t}(80)=-12.809, \mathrm{p}=$ .000. In the similar way, differences of significant value existed in Q2, Q3, Q4, and Q5.

Table 4. Paired Samples T-Test of Participative Leadership: T-Test Outcome Q6Q11. Difference between Pre-ODI and Post-ODI of Participative Leadership

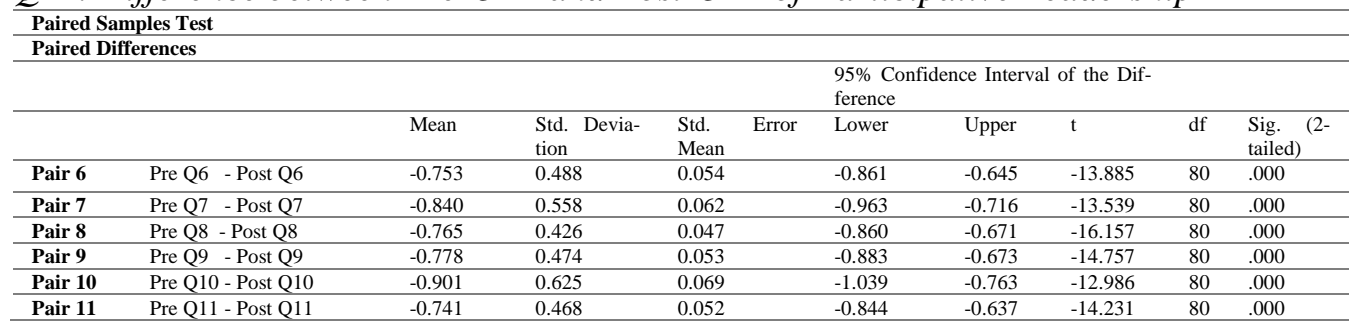

Source: Own study. 
In Table 4, the different significant scores are for Q6 without ODI $(\mathrm{M}=2.95, \mathrm{SD}=$ $0.80)$ and Q6 with ODI $(\mathrm{M}=3.7, \mathrm{SD}=0.58), \mathrm{t}(80)=-13.885, \mathrm{p}=.000$. In the similar way, differences of significant value existed in Q7, Q8, Q9, Q10, and Q11.

Table 5. Paired Samples T-Test of Extrinsic Motivation: T-Test Outcome Q12- Q16 Difference between Pre-ODI and Post-ODI of Extrinsic Motivation

\begin{tabular}{|c|c|c|c|c|c|c|c|c|c|c|}
\hline \multicolumn{11}{|c|}{ Paired Samples Test } \\
\hline \multicolumn{11}{|c|}{ Paired Differences } \\
\hline & & \multicolumn{9}{|c|}{$\begin{array}{l}95 \% \text { Confidence Interval of the Dif- } \\
\text { ference }\end{array}$} \\
\hline & & Mean & $\begin{array}{l}\text { Std. Devia- } \\
\text { tion }\end{array}$ & $\begin{array}{l}\text { Std. } \\
\text { Mean }\end{array}$ & Error & Lower & Upper & $\mathrm{t}$ & df & $\begin{array}{l}\text { Sig. (2- } \\
\text { tailed) }\end{array}$ \\
\hline Pair 12 & Pre Q12 - Post Q12 & -0.753 & 0.488 & 0.054 & & -0.861 & -0.645 & -13.885 & 80 & .000 \\
\hline Pair 13 & Pre Q13 - Post Q13 & -1.160 & 0.782 & 0.087 & & -1.333 & -0.988 & -13.357 & 80 & .000 \\
\hline Pair 14 & Pre Q14 - Post Q14 & -1.049 & 0.773 & 0.086 & & -1.220 & -0.878 & -12.218 & 80 & .000 \\
\hline Pair 15 & Pre Q15 - Post Q15 & -0.877 & 0.533 & 0.059 & & -0.995 & -0.759 & -14.788 & 80 & .000 \\
\hline Pair 16 & Pre Q16 - Post Q16 & -1.123 & 0.781 & 0.087 & & -1.296 & -0.951 & -12.951 & 80 & .000 \\
\hline
\end{tabular}

Source: Own study.

In Table 5, the different significant scores for Q13 are, without ODI $(\mathrm{M}=2.4, \mathrm{SD}=$ $1.24)$ and Q6 with ODI $(\mathrm{M}=3.56, \mathrm{SD}=0.59), \mathrm{t}(80)=-13.357, \mathrm{p}=.000$. In the similar way, differences of significant value existed in Q12, Q14, Q15 and Q16.

Table 6. Paired Samples T-Test of Intrinsic Motivation: T-Test Outcome Q17-Q21. Difference between Pre-ODI and Post-ODI of Intrinsic Motivation

\begin{tabular}{|c|c|c|c|c|c|c|c|c|c|}
\hline \multicolumn{10}{|c|}{ Paired Samples Test } \\
\hline \multicolumn{10}{|c|}{ Paired Differences } \\
\hline & & & & & $95 \% \mathrm{Cc}$ & Interva & Difference & & \\
\hline & & Mean & $\begin{array}{l}\text { Std. Devia- } \\
\text { tion }\end{array}$ & $\begin{array}{l}\text { Std. Error } \\
\text { Mean }\end{array}$ & Lower & Upper & $\mathrm{t}$ & df & $\begin{array}{l}\text { Sig. (2- } \\
\text { tailed) }\end{array}$ \\
\hline Pair 17 & Pre Q17 - Post Q17 & -0.753 & 0.488 & 0.054 & -0.861 & -0.645 & -13.885 & 80 & 0 \\
\hline Pair 18 & Pre Q18 - Post Q18 & -0.827 & 0.587 & 0.065 & -0.957 & -0.697 & -12.679 & 80 & 0 \\
\hline Pair 19 & Pre Q19 - Post Q19 & -0.951 & 0.705 & 0.078 & -1.107 & -0.795 & -12.129 & 80 & 0 \\
\hline Pair 20 & Pre Q20 - Post Q20 & -1.136 & 0.771 & 0.086 & -1.306 & -0.965 & -13.265 & 80 & 0 \\
\hline Pair 21 & Pre Q21 - Post Q21 & -0.914 & 0.674 & 0.075 & -1.063 & -0.764 & -12.190 & 80 & 0 \\
\hline
\end{tabular}

Source: Own study.

In Table 6, the different significant scores for Q20 are, without ODI $(\mathrm{M}=2.09, \mathrm{SD}=$ $1.05)$ and $\mathrm{Q} 20$ with ODI $(\mathrm{M}=3.22, \mathrm{SD}=0.50), \mathrm{t}(80)=-13.265, \mathrm{p}=.000$. In the similar way, differences of significant value existed in Q17, Q18, Q19 and Q21.

Table 7. Paired Samples T-Test of Employee Engagement Involvement: T-Test Outcome Q17- Q21. Difference between Pre-ODI and Post-ODI of Employee Engagement Involvement

\begin{tabular}{|c|c|c|c|c|c|c|c|c|c|c|}
\hline \multicolumn{11}{|c|}{ Paired Samples Test } \\
\hline \multicolumn{11}{|c|}{ Paired Differences } \\
\hline & & \multirow[b]{2}{*}{ Mean } & \multirow[b]{2}{*}{$\begin{array}{l}\text { Std. Devia- } \\
\text { tion }\end{array}$} & \multirow[b]{2}{*}{$\begin{array}{l}\text { Std. } \\
\text { Mean }\end{array}$} & \multirow[b]{2}{*}{ Error } & \multicolumn{3}{|c|}{$\begin{array}{l}95 \% \text { Confidence Interval of the Differ- } \\
\text { ence }\end{array}$} & \multirow[b]{2}{*}{ df } & \multirow[b]{2}{*}{$\begin{array}{l}\text { Sig. }(2- \\
\text { tailed) }\end{array}$} \\
\hline & & & & & & Lower & Upper & $\mathrm{t}$ & & \\
\hline Pair 22 & Pre Q22 - Post Q22 & -1.111 & 0.707 & 0.079 & & -1.267 & -0.955 & -14.142 & 80 & .000 \\
\hline Pair 23 & Pre Q23 - Post Q23 & -1.568 & 0.523 & 0.058 & & -1.684 & -1.452 & -26.985 & 80 & .000 \\
\hline Pair 24 & Pre Q24 - Post Q24 & -0.753 & 0.462 & 0.051 & & -0.855 & -0.651 & -14.676 & 80 & .000 \\
\hline Pair 25 & Pre Q25 - Post Q25 & -0.741 & 0.468 & 0.052 & & -0.844 & -0.637 & -14.231 & 80 & .000 \\
\hline Pair 26 & Pre Q26 - Post Q26 & -0.741 & 0.468 & 0.052 & & -0.844 & -0.637 & -14.231 & 80 & .000 \\
\hline
\end{tabular}

Source: Own study. 
The Impact of an ODI on the Development of Leadership, Employee Motivation 28 and Employee Engagement towards Better Performance of Employees: A Case Study

In Table 7, the different significant scores for Q23 are, without ODI $(\mathrm{M}=1.59, \mathrm{SD}=$ $0.85)$ and $\mathrm{Q} 23$ with ODI $(\mathrm{M}=3.16, \mathrm{SD}=0.51), \mathrm{t}(80)=-26.985, \mathrm{p}=.000$. In the similar way, differences of significant value existed in Q22, Q24, Q25 and Q26.

Table 8. Paired Samples T-Test of Employee Engagement Communication: T-Test Outcome Q27- Q33. Difference between Pre-ODI and Post-ODI of Employee Engagement Communication

\begin{tabular}{|c|c|c|c|c|c|c|c|c|c|c|}
\hline \multicolumn{11}{|c|}{ Paired Samples Test } \\
\hline \multicolumn{11}{|c|}{ Paired Differences } \\
\hline & & \multicolumn{9}{|c|}{$\begin{array}{l}\text { 95\% Confidence Interval of the Differ- } \\
\text { ence }\end{array}$} \\
\hline & & Mean & $\begin{array}{l}\text { Std. Devia- } \\
\text { tion }\end{array}$ & $\begin{array}{l}\text { Std. } \\
\text { Mean }\end{array}$ & Error & Lower & Upper & $\mathrm{t}$ & df & $\begin{array}{l}\text { Sig. } \\
\text { tailed })\end{array}$ \\
\hline Pair 27 & Pre Q27 - Post Q27 & -0.753 & 0.488 & 0.054 & & -0.861 & -0.645 & -13.885 & 80 & .000 \\
\hline Pair 28 & Pre Q28 - Post Q28 & -0.778 & 0.524 & 0.058 & & -0.894 & -0.662 & -13.348 & 80 & .000 \\
\hline Pair 29 & Pre Q29 - Post Q29 & -0.778 & 0.524 & 0.058 & & -0.894 & -0.662 & -13.348 & 80 & .000 \\
\hline Pair 30 & Pre Q30 - Post Q30 & -0.778 & 0.524 & 0.058 & & -0.894 & -0.662 & -13.348 & 80 & .000 \\
\hline Pair 31 & Pre Q31 - Post Q31 & -0.988 & 0.433 & 0.048 & & -1.083 & -0.892 & -20.536 & 80 & .000 \\
\hline Pair 32 & Pre Q32 - Post Q32 & -0.778 & 0.524 & 0.058 & & -0.894 & -0.662 & -13.348 & 80 & .000 \\
\hline Pair 33 & Pre Q33 - Post Q33 & -0.741 & 0.468 & 0.052 & & -0.844 & -0.637 & -14.231 & 80 & .000 \\
\hline Pair 26 & Pre Q26 - Post Q26 & -0.741 & 0.468 & 0.052 & & -0.844 & -0.637 & -14.231 & 80 & .000 \\
\hline
\end{tabular}

Source: Own study.

According to Table 8, the different significant scores for Q31 are, without ODI (M = $2.91, \mathrm{SD}=0.95)$ and Q31 with ODI $(\mathrm{M}=3.90, \mathrm{SD}=0.85), \mathrm{t}(80)=-20.536, \mathrm{p}=.000$. In the similar way, differences of significant value existed in Q27, Q28, Q29, Q30, Q32 and Q33.

Table 9. Paired Samples T-Test of Employee Individual Performance: T-Test Outcome Q34- Q40. Difference between Pre-ODI and Post-ODI of Employee Individual Performance

\begin{tabular}{|c|c|c|c|c|c|c|c|c|c|}
\hline \multicolumn{10}{|c|}{ Paired Samples Test } \\
\hline \multicolumn{10}{|c|}{ Paired Differences } \\
\hline & & \multirow[b]{2}{*}{ Mean } & \multirow[b]{2}{*}{$\begin{array}{l}\text { Std. Devia- } \\
\text { tion }\end{array}$} & \multirow[b]{2}{*}{$\begin{array}{l}\text { Std. } \\
\text { Mean }\end{array}$} & \multicolumn{3}{|c|}{$\begin{array}{l}\text { 95\% Confidence Interval of the Differ- } \\
\text { ence }\end{array}$} & \multirow[b]{2}{*}{ df } & \multirow[b]{2}{*}{$\begin{array}{l}\text { Sig. (2- } \\
\text { tailed) }\end{array}$} \\
\hline & & & & & Lower & Upper & $\mathrm{t}$ & & \\
\hline Pair 34 & Pre Q34 - Post Q34 & -0.938 & 0.509 & 0.057 & -1.051 & -0.826 & -16.604 & 80 & .000 \\
\hline Pair 35 & Pre Q35 - Post Q35 & -0.728 & 0.448 & 0.050 & -0.827 & -0.629 & -14.647 & 80 & .000 \\
\hline Pair 36 & Pre Q36 - Post Q36 & -0.753 & 0.488 & 0.054 & -0.861 & -0.645 & -13.885 & 80 & .000 \\
\hline Pair 37 & Pre Q37 - Post Q37 & -1.272 & 0.548 & 0.061 & -1.393 & -1.150 & -20.884 & 80 & .000 \\
\hline Pair 38 & Pre Q38 - Post Q38 & -0.877 & 0.640 & 0.071 & -1.018 & -0.735 & -12.327 & 80 & .000 \\
\hline Pair 39 & Pre Q39 - Post Q39 & -0.926 & 0.667 & 0.074 & -1.073 & -0.779 & -12.500 & 80 & .000 \\
\hline Pair 40 & Pre Q40 - Post Q40 & -1.284 & 0.575 & 0.064 & -1.411 & -1.157 & -20.089 & 80 & .000 \\
\hline
\end{tabular}

Source: Own study.

According to Table 9, the different significant scores for Q40 are, without ODI $(\mathrm{M}=$ 2.05, $\mathrm{SD}=0.92)$ and Q40 with ODI $(\mathrm{M}=3.33, \mathrm{SD}=0.57), \mathrm{t}(80)=-20.089, \mathrm{p}=.000$. In the similar way, differences of significant value existed in Q34, Q35, Q36, Q37, Q38 and Q39.

Table 10. Paired Samples T-Test of Employee Team Performance: T-Test Outcome Q41-Q46. Difference between Pre-ODI and Post-ODI of Employee Team Performance

\begin{tabular}{ll}
\hline Paired Samples Test & \\
\hline Paired Differences & $\begin{array}{l}95 \% \text { Confidence Interval of the Dif- } \\
\text { ference }\end{array}$ \\
\hline
\end{tabular}




\begin{tabular}{|c|c|c|c|c|c|c|c|c|c|c|}
\hline & & Mean & $\begin{array}{l}\text { Std. Devia- } \\
\text { tion }\end{array}$ & $\begin{array}{l}\text { Std. } \\
\text { Mean }\end{array}$ & Error & Lower & Upper & $\mathrm{t}$ & df & $\begin{array}{l}\text { Sig. (2- } \\
\text { tailed) }\end{array}$ \\
\hline Pair 42 & Pre Q42 - Post Q42 & -0.765 & 0.507 & 0.056 & & -0.877 & -0.653 & -13.594 & 80 & .000 \\
\hline Pair 43 & Pre Q43 - Post Q43 & -0.938 & 0.677 & 0.075 & & -1.088 & -0.789 & -12.469 & 80 & .000 \\
\hline Pair 44 & Pre Q44 - Post Q44 & -0.753 & 0.488 & 0.054 & & -0.861 & -0.645 & -13.885 & 80 & .000 \\
\hline
\end{tabular}

Source: Own study.

According to Table 10, the different significant scores for Q43 are, without ODI (M $=2.53, \mathrm{SD}=1.14)$ and $\mathrm{Q} 43$ with ODI $(\mathrm{M}=3.46, \mathrm{SD}=0.67), \mathrm{t}(80)=-12.469, \mathrm{p}=$ .000. In the similar way, differences of significant value existed in Q41, Q42, Q44, Q45 and Q46.

Table 11. Paired Sample T Test of PRE and POST ODI Result. Paired Sample T Test of PRE and POST ODI Result

\begin{tabular}{llcccc}
\hline Variable & \multicolumn{2}{l}{ Paired Differences } & \multicolumn{2}{c}{$\begin{array}{c}\text { Sig. } \\
\text { tailed) }\end{array}$} \\
\cline { 2 - 4 } & Mean & $\begin{array}{l}\text { Std. Devia- } \\
\text { tion }\end{array}$ & Std. Error Mean & \\
\hline Pair 1: Pre-Post Leadership & -0.84175 & 0.44878 & 0.04986 & -16.881 \\
\hline Pair 2: Pre-Post Motivation & -0.95432 & 0.58353 & 0.06484 & -14.719 & 0.000 \\
\hline Pair 3: Pre-Post Employee Engagement & -0.87551 & 0.40934 & 0.04548 & -19.25 & 0.000 \\
\hline Pair 4: Pre-Post Employee Performance & -0.88034 & 0.42604 & 0.04734 & -18.597 & 0.000 \\
\hline
\end{tabular}

Source: Own study.

Table 11 showed the PRE and POST ODI analyzed result of Paired Sample T test.

Pair 1: Pre-Post Leadership's mean result is -0.84175 which mean the POST ODI's mean value is more higher than PRE mean value, Std. Deviation value is 0.44878 which mean that there is no significant problems in PRE and POST ODI of Leadership, Std. Error Mean value also 0.04986 which mean there is no strong error and Sig. (2-tailed) result is 0.000 which mean PRE and POST ODI of Leadership is significantly different.

Pair 2: Pre-Post Motivation's mean result is -0.95432 which mean the POST ODI's mean value is more higher than PRE mean value, Std. Deviation value is 0.58353 which mean that there is no significant problems in PRE and POST ODI of Motivation, Std. Error Mean value also 0.06484 which mean there is no strong error and Sig (2-tailed) result is 0.000 which mean PRE and POST ODI of Motivation is significantly different.

Pair 3: Pre-Post Employee Engagement's mean result is -0.87551 which mean the POST ODI's mean value is more higher than PRE mean value, Std. Deviation value is 0.40934 which mean that there is no significant problems in PRE and POST ODI of Employee Engagement, Std Error Mean value also 0.04548 which mean there is no strong error and Sig (2-tailed) result is 0.000 which mean PRE and POST ODI of Employee Engagement is significantly different.

Pair 4: Pre-Post Employee Performance's mean result is -0.88034 which mean the POST ODI's mean value is more higher than PRE mean value, Std.Deviation value is 0.42604 which mean that there is no significant problems in PRE and POST ODI 
The Impact of an ODI on the Development of Leadership, Employee Motivation 30 and Employee Engagement towards Better Performance of Employees: A Case Study

of Employee Performance, Std Error Mean value also 0.04734 which mean there is no strong error and Sig (2-tailed) result is 0.000 which mean PRE and POST ODI of Employee Performance is significantly different.

Table 12. Wilcoxon Signed-Rank Test of Variables. Wilcoxon Signed Rank Test of Variables

\begin{tabular}{|c|c|c|c|c|c|c|}
\hline \multirow{2}{*}{ Variable } & & \multirow{2}{*}{$\mathbf{N}$} & \multirow{2}{*}{$\begin{array}{l}\text { Mean } \\
\text { Rank }\end{array}$} & \multirow{2}{*}{$\begin{array}{l}\text { Sum of } \\
\text { Ranks }\end{array}$} & \multicolumn{2}{|c|}{ Test Statistics } \\
\hline & & & & & $\mathbf{Z}$ & Sig. (2-tailed) \\
\hline \multirow{4}{*}{$\begin{array}{l}\text { Pair 1: Post-Pre } \\
\text { Leadership }\end{array}$} & Negative Ranks & $0^{\mathrm{a}}$ & 0.0 & 0.0 & \multirow{4}{*}{-7.524} & \multirow{4}{*}{0.000} \\
\hline & Positive Ranks & $74^{\mathrm{b}}$ & 37.5 & 2775.0 & & \\
\hline & Ties & $7^{c}$ & & & & \\
\hline & Total & 81 & & & & \\
\hline \multirow{4}{*}{$\begin{array}{l}\text { Pair 2: Post-Pre Mo- } \\
\text { tivation }\end{array}$} & Negative Ranks & $0^{\mathrm{d}}$ & 0.0 & 0.0 & \multirow{4}{*}{-7.083} & \multirow{4}{*}{0.000} \\
\hline & Positive Ranks & $66^{\mathrm{e}}$ & 33.5 & 2211.0 & & \\
\hline & Ties & $15^{\mathrm{f}}$ & & & & \\
\hline & Total & 81 & & & & \\
\hline \multirow{4}{*}{$\begin{array}{l}\text { Pair 3: } \\
\text { Employee } \\
\text { ment }\end{array}$} & Negative Ranks & $0^{\mathrm{g}}$ & 0.0 & 0.0 & \multirow{4}{*}{-7.852} & \multirow{4}{*}{0.000} \\
\hline & Positive Ranks & $81^{\mathrm{h}}$ & 41.0 & 3321.0 & & \\
\hline & Ties & $0^{\mathrm{i}}$ & & & & \\
\hline & Total & 81 & & & & \\
\hline \multirow{4}{*}{$\begin{array}{l}\text { Pair 4: } \\
\text { Employee } \\
\text { mance }\end{array}$} & Negative Ranks & $0^{j}$ & 0.0 & 0.0 & \multirow{4}{*}{-7.855} & \multirow{4}{*}{0.000} \\
\hline & Positive Ranks & $81^{\mathrm{k}}$ & 41.0 & 3321.0 & & \\
\hline & Ties & $0^{1}$ & & & & \\
\hline & Total & 81 & & & & \\
\hline
\end{tabular}

Source: Own study.

\section{Hypothesis 1:}

According to Paired Sample T Test of Pre ODI and POST ODI of leadership showed in Table 11, $\mathrm{t}=-16.881$ and $\mathrm{p}$ value of the pair is .000 less than .05 (95\% difference interval confidence) and the result is statistically significant different between PRE ODI and POST ODI. Furthermore, Wilcoxon signed-rank test of Pre-ODI and PostODI of Leadership show in Table 12 indicate that $\mathrm{z}=-7.524$ and the $\mathrm{p}$ value of the pair showed .000 less than .05 (at 95\% Confidence Interval of the Difference), indicating there is a statistically significant difference between Pre and Post ODI. Thus, observing the support of $\mathbf{H 1} \mathbf{1}_{\mathbf{a}}$ there is a statistically significant difference between PRE ODI and POST ODI of Leadership.

\section{Hypothesis 2:}

According to Paired Sample T Test of Pre ODI and POST ODI of motivation showed in Table 11, $\mathrm{t}=-14.719$ and $\mathrm{p}$ value of the pair is .000 less than .05 (95\% difference interval confidence) and the result is statistically significant different between PRE ODI and POST ODI. Moreover, Wilcoxon signed-rank test of Pre-ODI and Post-ODI of Motivation show in Table 12 indicate that $\mathrm{z}=-7.083$ and the $\mathrm{p}$ value of the pair showed .000 less than .05 (at 95\% Confidence Interval of the Difference), indicating there is a statistically significant difference between Pre and Post ODI. Therefore, finding the support of $\mathbf{H} \mathbf{2}_{\mathbf{a}}$ there is a statistically significant difference between PRE ODI and POST ODI of Motivation.

\section{Hypothesis 3:}

In the Table 11, Paired Sample T Test of Pre ODI and POST ODI of Employee Engagement showed $t=-19.25$ and $p$ value of the pair is .000 less than .05 (95\% difference interval confidence) and the result is statistically significant different between PRE ODI and POST ODI on Employee Engagement. In addition, Wilcoxon-signed 
rank test of Pre-ODI and Post-ODI of Employee Engagement show in Table 12 indicate that $\mathrm{z}=-7.852$ and the $\mathrm{p}$ value of the pair showed .000 less than .05 (at $95 \%$ Confidence Interval of the Difference), indicating there is a statistically significant difference between Pre and Post ODI. Therefore, finding the support of $\mathbf{H} \mathbf{3}_{\mathbf{a}}$ there is a statistically significant difference between PRE ODI and POST ODI of Employee Engagement.

\section{Hypothesis 4:}

According to Paired Sample T Test of Pre ODI and POST ODI of Employee Performance showed in Table $11, \mathrm{t}=-18.597$ and $\mathrm{p}$ value of the pair is .000 less than .05 (95\% difference interval confidence) and the result is statistically significant different between PRE ODI and POST ODI. Moreover, Wilcoxon signed rank test of Pre-ODI and Post-ODI of Employee Performance show in Table 12 indicate that $\mathrm{z}=-7.855$ and the $\mathrm{p}$ value of the pair showed .000 less than .05 (at $95 \%$ Confidence Interval of the Difference), indicating there is a statistically significant difference between Pre and Post ODI. Thus, observing the support of $\mathbf{H} \mathbf{4}_{\mathbf{a}}$ there is a statistically significant difference between PRE ODI and POST ODI of Employee Performance.

According to statistical finding (Table 11 and Table 12) the result support Hypothesis 1 - Hypothesis 4 that there are significant differences between PRE ODI and POST ODI on Leadership, Motivation, Employee Engagement and Employee Performance.

Table 13. Leadership and Motivation Spearman Rank Correlation Test. Spearman Rank Correlation Test of Leadership - Employee Performance

Correlations

\begin{tabular}{|lll|l|l|}
\hline & & LEADERSHIP & $\begin{array}{l}\text { EMPLOYEE } \\
\text { FORMANCE }\end{array}$ \\
\hline Spearman's rho & LEADERSHIP & Correlation Coefficient & 1.000 & $.600^{* *}$ \\
& & Sig. (2-tailed) &. & .000 \\
& $\mathrm{~N}$ & 81 & 81 \\
\cline { 2 - 5 } & EMPLOYEE & PERFOR- Correlation Coefficient & $.600^{* *}$ & 1.000 \\
& MANCE & Sig. (2-tailed) & .000 &. \\
& $\mathrm{~N}$ & 81 & 81 \\
\hline
\end{tabular}

** Correlation is significant at the 0.01 level (2-tailed).

Source: Own study.

\section{Hypothesis 5:}

As indicated in Table 13, the result from Spearman Correlation analysis showed that the $r$ s value $=0.600$ and $\mathrm{p}$ value sig. is equal .000 which is less than $.05(.000<.05)$. It means that the null hypothesis is rejected. There is a statistical significant relationship between 2 variables at the .05 significant level. Therefore H5a: Leadership and Employee Performance are moderately correlated and have positive influence. 
The Impact of an ODI on the Development of Leadership, Employee Motivation 32 and Employee Engagement towards Better Performance of Employees: A Case Study

Table 14. Motivation and Employee Performance Spearman Rank Correlation Test. Spearman Rank Correlation Test of Motivation - Employee Performance

Correlations

\begin{tabular}{|lll|l|l|}
\hline & & MOTIVATION & $\begin{array}{l}\text { EMPLOYEE PER- } \\
\text { FORMANCE }\end{array}$ \\
\hline Spearman's rho & MOTIVATION & Correlation Coefficient & 1.000 & $.731^{* * *}$ \\
& & Sig. (2-tailed) & .000 \\
$\mathrm{~N}$ & 81 & 81 \\
\cline { 2 - 5 } & & $\mathrm{N}$ & 1.000 \\
& EMPLOYEE & PERFOR- Correlation Coefficient & $.731^{* *}$ & \\
& Sig. (2-tailed) & .000 & 81 \\
\hline & $\mathrm{N}$ & 81 & \\
\hline
\end{tabular}

** Correlation is significant at the 0.01 level (2-tailed).

Source: Own study.

\section{Hypothesis 6:}

In Table 14, the result from Spearman Correlation analysis showed that the $r$ s value $=0.731$ and $p$ value sig. is equal .000 which is less than $.05(.000<.05)$. It means that the null hypothesis is rejected. There is a statistical significant relationship between 2 variables at the .05 significant level. Therefore H6: Motivation and Employee Performance are moderately correlated and have relationship.

Table 15. Employee Engagement and Employee Performance Spearman Rank Correlation Test

Spearman Rank Correlation Test of Employee Engagement - Employee Performance Correlations

\begin{tabular}{|c|c|c|c|}
\hline & & $\begin{array}{l}\text { EMPLOYEE EN- } \\
\text { GAGEMENT }\end{array}$ & $\begin{array}{l}\text { EMPLOYEE } \\
\text { FORMANCE }\end{array}$ \\
\hline \multirow[t]{2}{*}{ Spearman's rho } & $\begin{array}{l}\text { EMPLOYEE ENGAGE- Correlation Coefficient } \\
\text { MENT } \\
\qquad \text { Sig. (2-tailed) } \\
\mathrm{N}\end{array}$ & $\begin{array}{l}1.000 \\
81\end{array}$ & $\begin{array}{l}.651^{* *} \\
.000 \\
81\end{array}$ \\
\hline & $\begin{array}{l}\text { EMPLOYEE } \\
\text { MANCEFOR- Correlation Coefficient } \\
\qquad \text { Sig. (2-tailed) } \\
\mathrm{N}\end{array}$ & $\begin{array}{l}.651^{* *} \\
.000 \\
81\end{array}$ & $\begin{array}{l}1.000 \\
81\end{array}$ \\
\hline
\end{tabular}

** Correlation is significant at the 0.01 level (2-tailed).

Source: Own study.

\section{Hypothesis 7:}

According to Table 15, the result from Spearman Correlation analysis showed that the $r$ s value $=0.651$ and $\mathrm{p}$ value sig. is equal .000 which is less than $.05(.000<.05)$. It means that the null hypothesis is rejected. There is a statistical significant relationship between 2 variables at the .05 significant level. Therefore H7 $\mathbf{a}$ : Employee Engagement and Employee Performance have moderately correlation and positively influence. 
Table 16. Leadership and Motivation Spearman Rank Correlation Test Spearman Rank Correlation Test of Leadership - Motivation Correlations

\begin{tabular}{|lll|l|l|}
\hline & & LEADERSHIP & MOTIVATION \\
\hline Spearman's rho & LEADERSHIP & Correlation Coefficient & 1.000 & $.454^{* *}$ \\
& & Sig. (2-tailed) &. & .000 \\
& $\mathrm{~N}$ & 81 & 81 \\
\cline { 2 - 5 } & & Correlation Coefficient & $.454^{* *}$ & 1.000 \\
& Sig. (2-tailed) & .000 &. \\
& $\mathrm{~N}$ & 81 & 81 \\
\hline
\end{tabular}

** Correlation is significant at the 0.01 level (2-tailed).

Source: Own study.

\section{Hypothesis 8}

Table 16, the result from Spearman Correlation analysis showed that the $r$ s value $=$ 0.454 and $\mathrm{p}$ value sig. is equal .000 which is less than $.05(.000<.05)$. It means that the null hypothesis is rejected. There is a statistical significant relationship between 2 variables at the .05 significant level. Therefore H8$_{\mathbf{a}}$ : Leadership and Motivation have moderately relationship.

Table 17. Motivation and Employee Engagement Spearman Rank Correlation Test. Spearman Rank Correlation Test of Motivation - Employee Engagement

Correlations

\begin{tabular}{|c|c|c|c|c|}
\hline & & & MOTIVATION & $\begin{array}{l}\text { EMPLOYEE ENGAGE- } \\
\text { MENT }\end{array}$ \\
\hline \multirow[t]{2}{*}{ Spearman's rho } & MOTIVATION & $\begin{array}{l}\text { Correlation Coefficient } \\
\text { Sig. (2-tailed) } \\
\mathrm{N}\end{array}$ & $\begin{array}{l}1.000 \\
81\end{array}$ & $\begin{array}{l}.551^{* *} \\
.000 \\
81\end{array}$ \\
\hline & $\begin{array}{l}\text { EMPLOYEE } \\
\text { GAGEMENT }\end{array}$ & $\begin{array}{l}\text { EN- Correlation Coefficient } \\
\qquad \begin{array}{l}\text { Sig. (2-tailed) } \\
\text { N }\end{array}\end{array}$ & $\begin{array}{l}.551^{* *} \\
.000 \\
81\end{array}$ & $\begin{array}{l}1.000 \\
81\end{array}$ \\
\hline
\end{tabular}

**Correlation is significant at the 0.01level(2-tailed).

Source: Own study.

\section{Hypothesis 9}

In Table 17, the result from Spearman Correlation analysis showed that the $r$ s value $=0.551$ and $p$ value sig. is equal .000 which is less than $.05(.000<.05)$. It means that the null hypothesis is rejected. There is a statistical significant relationship between 2 variables at the .05 significant level. Therefore $\mathbf{H 9}_{\mathbf{a}}$ : Motivation and Employee Engagement have moderately correlated.

According to Statistical finding (Table 13 to Table 17) the research's result support Hypothesis 5 to Hypothesis 9. 
The Impact of an ODI on the Development of Leadership, Employee Motivation 34 and Employee Engagement towards Better Performance of Employees: A Case Study

\section{Result Summary and Discussion}

The key factors of this research was developing with reference to Leadership, Motivation, and Employee Engagement to improve the Employee Performance in the OV Logistic Myanmar proving that each variable have a relationship. During the preliminary stage, the researchers took the interview with executive and the feedback was "Manager are work properly but don't have enough skills to solve the problems in the organization", "Seem like manager and subordinate have miscommunication in internal organization", "They been working with OV Logistics more than 10 years over and seem like loyalty but not effective in work" and "Subordinate are willing to help and do in the organization but there is no direct order from managers".

The researchers took the one to one interview with employees in the organization, their feedback was managers are not good, management skill is poor and leadership skill is not effective in the organization. But during the PRE ODI period the survey questionnaire analyzed of overall directive and participative leadership' median score is 3.00 which neutral and the employee did not responded worse. In the ODI process time also all the managers are enthusiastically participate in the ODI process. According to overall median of Leadership scores in POST ODI is 4.00 and the percent improvement rate is $33 \%$ improving after the ODI process. Therefore ODI is effective to the Leadership.

Since preliminary stage, most of the employees are demotivate to engage the job task in the organization and during the global pandemic period the organization's economy was getting worse and all the employees were cut their salary. But during the preliminary stage the employee mention their feeling but PRE ODI of Motivation's median score is 3.00 and it's neutral. But the researchers found out lack of "training and personal development opportunities for my good work", "monetary rewards/ bonus for my skilful work", "I got a praise and recognition from my managers for my works" and "I received symbolic public recognition for my work" in the organization during PRE ODI in the Employee Survey Questionnaire. In the ODI process all the employee are willing to participate the training and workshop. Because of the employee's willing participant the POST ODI result showed the improvement. The percent Improvement rate of PRE ODI and POST ODI of Motivation is 33\%. Therefore ODI process is effected to Employee's motivation.

According to preliminary stage, executive responded "Subordinate are willing to help and do in the organization but there is no direct order from managers". Comparison of PRE ODI and POST ODI of Employee Engagement Involvement have 33\% improvement but Employee Engagement Communication don't have improvement and the answers is neutral. But Overall Employee Engagement have 17\% improvement. ODI process training is only 7 weeks long, which not enough to fix the internal organization's conflict and communication problems. That why the ODI process is weekly effective to Employee Engagement Communication. 
In the Employee Individual Performance and Employee Team Performance, the PRE ODI and POST ODI's data analyzed showed there is improvement between PRE ODI and POST ODI. At the PRE ODI of Overall Employee Performance's median score is 3.00 and POST ODI of Overall Employee Performance's median score is 4.00, the percent improvement rate is $33 \%$ between PRE ODI and POST ODI. That why ODI process is effected on Employee Performance.

Nowadays, the global economy is driven constantly into innovation, profitability and performance. The effective leadership can effect on the organization development, social communication, work function, employee performance and organizational performance. The ineffective leadership skills lead the organization into many problems such as unclear decision making, poor job handling, employee and organizational mismanagement, organization performance. That why leadership is the most important to the organization. Many study had proven that the leadership skills and employee performance have a strong relationship. In this research the researcher proof that Hypothesis H5a: Leadership and Employee Performance are moderately correlated and have positive influence.

In this evolution development time, employee performance become the major topic in the organization, that why employee have to be practically well train and motivate to engage job task to achieve the organizational performance. Previously in the OV Logistic, the organization did not offer a proper training to employee and during global pandemic most of the employee had been salary cut is the one of the reason to employee demotivate. Another reason is most of the employee are they feel that they are out of the organization, they don't have opportunities in the organization, managers and executive have a good relation that why they got benefits. That why employee become demotivate, less job engagement and internal communication problems.

In the ODI process, most of the trainers are closely guide to managers and employee, training them what is leadership, what is job row, what is basic knowledge in modern organization, etc. All managers and employees are participate in the training very well and the outcome result are acceptable and found improvement. Therefore in this research proved that Hypothesis H6: Motivation and Employee Performance are moderately correlated and have relationship; and Hypothesis $\mathbf{H 7} \mathbf{a}$ : Employee Engagement and Employee Performance are moderately correlated and have relationship.

Motivation is the major important factors to drive the employees' performance because employee who are not employed in the right job will fail, employee who demotivate will fail the employee engagement and employee performance. In the organization mis-leadership lead into employees' less engagement and demotivation. In this research the researcher found out that most of the employee are demotivate during the preliminary period, but when the researcher collected the PRE ODI survey, the result are neutral and there is no underline problems. As the researcher mention above the employee status during the preliminary period, but after the ODI process and POST ODI result prove that Employees' motivation and Engagement have an 
The Impact of an ODI on the Development of Leadership, Employee Motivation 36 and Employee Engagement towards Better Performance of Employees: A Case Study

improvement. Therefore Hypothesis $\mathbf{H} \mathbf{8}_{\mathbf{a}}$ : Leadership and Motivation have moderately correlated and have relationship; and Hypothesis $\mathbf{H 9}_{\mathbf{a}}$ : Motivation and Employee Engagement have moderately correlated and have relationship. In this research, researcher prove variables' percent improvement and relationship.

\section{References:}

Abdul Basit, Veronica Sebastian, Zubair Hassan. (2017). Impact of Leadership Style on Employee Performance (A Case Study on a Private Organization in Malaysia)

Abdullah, Z., Ahsan, N., \& Alam, S. S. (2009). The effect of human resource management practices on business performance among private companies in Malaysia. International Journal of Business and Management, 4(6), 65.

Ademola Adeleke (2008). "Cocksparrow Diplomacy": Percy Spender, The Colombo Plan And Commonwealth Relations

Akerlof, G. A., \& Kranton, R. E. (2010). Identity economics: How our identities shape our work, wages, and well-being. Princeton University Press

Albert Puni, Abednego Okoe, Samuel Ofei (2014). The Effect of Leadership Styles on Firm Performance in Ghana

Amabile, T. M., Hil, K. G., Hennessey, B. A., \& Tighe, E. M. (1995). "The Work Preference Inventory: Assessing intrinsic and extrinsic motivational orientations": Correction. Journal of Personality and Social Psychology, 68(4), 580

Anantatmula, V. (2007). Linking KM effectiveness attributes to organizational performance. Vine, 37(2), 133-149

Anbuoli, P., \& Devibala, V. (2009). A Study on Employee Engagement in Insurance Sector in Madurai. Singaporean Journal Scientific Research, 2.

Andre de Wall, Beatrice Van Der Heijden. (2015). The Role of Performance Management in Creating and Maintaining a High- Performance Organization

Anit Somech (2006). The Effects of Leadership Style and Team Process on Performance and Innovation in Functionally Heterogeneous Teams

Antony, J. P.,\& Bhattacharya, S. (2010). Measuring organizational performance and organizational excellence of SMEs -Part 2: an empirical study on SMEs in India. Measure Business Excellence, 14(3), 42-52.

Alhusaini, S. S. A. (2012). The Effects of Leadership Styles on Job Performance: A Case Study in the Ministry of Telecommunications in Yemen. University Utara Malaysia

Alonso, P., \& Lewis, G. B. (2001). Public Service Motivation and Job Performance Evidence from the Federal Sector. The American Review of Public Administration, 31(4), 363-380.

Altarawneh, Albdour, A.A., I.I. (2014) Employee Engagement and Organizational Commitment; Evidence from Jordan. International Journal of Business, 19, 192-212.

A.T.Kearney. (2019). Asia Logistics Report

Atkinson, J.W. (1957). Motivational determinants of risk-taking behavior. Psychological Review, 64(6, Pt.1)

Bass, B.M. and Avolio, B.J. (1997), "Full Range Leadership Development: Manual for the Multifactor Leadership Questionnaire," Mind Garden Inc., Redwood City.

Bass, B.M. (1997). “Concepts of Leadership”. In Vecchio, R.P. (ed). Leadership: Understanding the Dynamics of Power and Influence in Organizations. Notre Dame: University of Notre Dame Press

Ben Shepherd and Shintaro Hamanaka. (2015). Enhancing International Trade Logistics Performance: Inclusive Development and Supply Chain Efficiency: Asia-Pacific Trade Facilitation Forum. 
Bernhard Tilanus (1997). Information Systems in Logistics and Transportation

B.M. Shuck, T. S. Rocco, and C. A. Albornoz (2011). "Exploring Employee engagement from the employee perspective: Implication for HRD", Journal of European Industrial training, vol. 35, issue 4, 300-325.

Blake, R. R., \& Mouton, J. S. (1964). The managerial grid. Houston, TX: Gulf Publishing

Brown, D.R. (2011). An Experimental Approach to Organizational Development (8th Ed). USA, Pearson Education.

Charlotte Lærke Weitze, Digital and Creative Learning Lab and Rikke Ørngreen Aalborg University. (2012). Concept Model for Designing Engaging and Motivating Games for Learning-The Smiley-Model

Chen, M. F., \& Lien, G. Y. (2008). The Mediating Role of Job Stress in Predicting Retail Banking Employees' Turnover Intentions in Taiwan. International Conference on Service Operations and Logistics and Informatics, Vols 1 and 2, 393-398.

Christina Maslach, Wilmar B. Schaufeli, and Michael P. Leiter. (2001). Job Burnout

Chowdhury, M. (2007). Enhancing motivation and work performance of the salespeople: the impact of supervisors' behavior. African Journal of Business Management, 1(9).

C. John Langley, Jr., Ph.D., and Infosys. (2019). Third Party Logistics Study:The State of Logistics Outsourcing

Clement Bell. (2014). The Impact of Participative and Directive Leadership on Organizational Culture: An Organizational Development Perspective: Fort Hare University

Cohen, W.A. (1990) The Art of the Leader. Prentice Hall, Englewood Cliffs

Creswell, J. (2008): Educational Research, Pearson Education International

Cribbin, James J (1981). Leadership: Strategies for Organizational Effectiveness

Cris Wildermuth, Patrick David Pauken. (2008). A perfect match: Decoding employee engagement- Part II: Engaging jobs and individuals

Cummings, L.L. and Schwab, D.P. 1973. Performance in organizations: Determinants and Appraisal. Glenview: Scott, Foreman and Company.

Daniel C. Molden. (2000). Meaning and Motivation: Northwestern University

Danielle Mcdonald, Abbie Smith. (1995). A Proven Connection: Performance Management and Business Results

David C McClelland (1953). The achievement motivation: New York, Appleton-CenturyCrofts

David R.Coole. (2003). The Effects of Citizenship Performance, Task Performance, and Rating Format on Performance Judgments

Debra Howcroft, Melanie Wilson. (2003). Paradoxes of participatory practices: The Janus role of the systems developer

Denison, D. R., \& Neale, W. S. (1996). Denison organizational culture survey: Facilitator's guide. Ann Arbor, MI: Aviat.

Denscombe, M. (1998), The Good Research Guide for Small Scale Research Projects. Buckingham: Open University Press

Dick, B. (2000a). A beginner's guide to action research. Retrieved 9 March 2015

Dweck, C. S., \& Elliott, E. S. (1983). Achievement Motivation. In P. H. Mussen (Gen. Ed.), \& E. M. Hetherington (Ed.), Handbook of Child Psychology (Vol. 4, pp. 643-691).

Edward L.Deci, Richard M.Ryan. (2020). Intrinsic and extrinsic motivation from a self-determination theory perspective: Definitions, theory, practices, and future directions

Emmanuel Osei Boakye (2015). The impact of teamwork on employee performance Fiedler, F. E. (1995). Cognitive resources and leadership performance. Applied Psychology: An International Review, 44, 5-28

Englewood Cliffs. Ivancevich, John M. William F. Glueck. (1989). Foundations of Personnel/Human Management. 21397-409. 
The Impact of an ODI on the Development of Leadership, Employee Motivation 38 and Employee Engagement towards Better Performance of Employees: A Case Study

Fleenor, J. W. \& Bryant, C. (2002). Leadership Effectiveness and Organizational Culture: An Exploratory Study. Centre for Creative Leadership, Toronto; Canada.

Florian, G. I. (2013). Understanding the determinants of firms' performance. SEA-Practical Application of Science, 1(2).

Funda Yercan, Turkay Yildiz. (2012, May). International maritime trade and logistics

Gadot, E. V. (2007), Leadership style, organizational politics, and employees' performance: An empirical examination of two competing models. Personnel Review, Volume 36, No. 5, pp. 661-683.

Gavrea, C., Illies, L.,\& Stegerean, R. (2011). Determinants of organizational performance: the case of Romania. Management \& Marketing Challenges for the Knowledge Society, 6(2), 285-300.

Ghaith Abdulraheem Ali Alsheikh, Enas Ali Theeb Alnawafleh, Mutia sobihah Abd Halim, Abdul

G.Muthuvel, G.Ramadoss.(2013). Challengers and Benefits future Trends of E-commerce Growth in India Business

Goffman, E. (1961). Asylums: Essays on the social situations of mental patients and other inmates. Doubleday (Anchor).

Grant, A. M., \& Berry, J. (2011). The Necessity of Others Is the Mother of Invention: Intrinsic and Prosocial Motivations, Perspective-Taking, and Creativity. Academy of Management Journal.

Griffin, Ricky W. (2004). Manajemen (7th ed.). Jakarta:Alih Bahasa, Penerbit Erlangga

Guest, D. (2002). Human resource management, corporate performance and employee wellbeing: Building the worker into HRM. The journal of industrial relations, 44(3), 335358

Guthrie, J. T., Alao, S., \& Rinehart, J. M. (1997). Engagement in reading for young adolescents. Journal of Adolescent \& Adult Literacy, 40.

Hackman JR. (1987). The design of work teams. In: Lorsch J Handbook of organizational behavior. Englewood Cliffs, NJ: Prentice-Hall.

Hamilton, F. and J. B. Cynthia (2005), The importance of context, beliefs and values in leadership development. Business Ethics: A European Review, Volume 14, No. 4.

Hanif, F. (2013). Impact of training on employee's development and performance in hotel industry of lahore, pakistan. Journal of business studies quarterly, 4(4), 68.

Hashmen Salarzadeh Jenatabadi. (2015, May). An Overview of Organizational Performance Index: Definitions and Measurements

Haozhe Chen, Iowa State University and Bruce G. Ferrin. (2011, May). Organizational Structure and Logistics Service Innovation: Western Michigan University

Heider, F. (1958). The psychology of interpersonal relations. John Wiley \& Sons Inc

Heneman, H.G., Judge, T.A., Kammeyer-Mueller J.D. (2012). Staffing Organizatons, 7th edition. Middleton, WI: McGraw-Hill International Edition

Hellriegel, Jackson \& Slocum. (1999). Management Dynamic Process

Hersey, P., \& Blanchard, K. (2005). Center for Leadership Studies 1. Journal Psicologi Social, 10, 271-301

Herzberg, F. (1986). One more time: How do you motivate employees? In J. N. Williamson (Ed.), The leader-manager (pp. 433-448).

Holt, Davis H. (1993). Management: Concept and Practices. New Jersey: Prentice Hall Ian O’ Boyle. (2013, March). Individual Performance Management: A Review of Current Practices: School of Management, University of South Australia

International Journal of Science and Research (IJSR) ISSN (Online): 2319-7064 Index Copernicus Value (2015): 78.96 | Impact Factor (2015): 6.391 
Ivankova, N. V. (2015). Mixed methods applications in action research: From methods to community action

Izhar Che Mee1, Haim Hilman. (2015). Application of Action Research Methodology in Developing a Framework for Identifying Unnecessary Regulatory Burdens on Business.

James, L. R., Choi, C. C., Ko, C. H. E., McNeil, P. K., Minton, M. K. \& Wright, M. A., et al. (2007). Organizational and psychological climate: A review of theory and research. European Journal of Work and Organizational Psychology, 17(1), 5-32

Jeet, V., \& Sayeeduzzafar, D. (2014). A study of HRM practices and its impact on employees job satisfaction in private sector banks: A case study of HDFC Bank. International Journal of Advance Research in Computer Science and Management Studies, 2(1), 6268.

Jenatabadi, H. S. (2015). An Overview of Organizational Performance Index: Definition and Measurement.

Joern Fischer, Maraja Riechers. (2019). A leverage points perspective on sustainability

John P. Campbell, Jeffrey J McHenry, Lauress L.Wise (1990).Modeling Job Performance in A Population of Jobs

Joo, B.-K., \& Lim, T. (2009). The effects of organizational learning culture, perceived job complexity, and proactive personality on organizational commitment and intrinsic motivation. Journal of Leadership \& Organizational Studies, 16(1), 48-60

Joseph E. Mroz, Michael Andrew Yoerger, Joseph Andrew Allen (2018). Leadership in Workplace Meetings: The Intersection of Leadership Styles and Follower Gender

Judith J. Msangi (2020). Human Resource Management Practices and Employees' Engagement in Small and Medium Enterprises in Tanzania: The Mediating Effect of Organization View

Kahn, W. A. (1990). Psychological conditions of personal engagement and disengagement at work. Academy of Management Journal,

Kanungo, R. N. (1982). Measurement of job and work involvement. Journal of Applied Psychology, 67(3), 341-349

Kaufmann, N., Schulze, T., Veit, D. (2011). "More than fun and money. Worker Motivation in Crowdsourcing - A Study on Mechanical Turk". AMCIS 2011 Proceedings

Kemmis S. \& McTaggert, R. (1990). The Action Research Reader. Deakin University Press

Kelley, H. H. (1967). Attribution theory in social psychology. Nebraska Symposium on Motivation, 15, 192-238

Klagge, J. (1997), Leadership development needs of today's organizational managers. Leadership and Organization Development Journal

Krathwohl, D.R. (1998), Educational \& Social Science Research: An Integrated Approach. New York: Longman.

Lalatendu Kesari Jena, Rabindra Kumar Pradhan (2016). Employee Performance at Workplace: Conceptual Model and Empirical Validation

Lee, L. T.-S., \& Sukoco, B. M. (2007). The effects of entrepreneurial orientation and knowledge management capability on organizational effectiveness in Taiwan: the moderating role of social capital. International Journal of Management, 24(3), 549

Lei Qi, Bing Liu, Xin Wei, Yanghong Hu. (2016, October). Impact of inclusive leadership on employee innovative behavior: Perceived organizational support as a mediator

Linda Koopmans, Claire Bernaards, Vincent Hildebrandt, Henrica De Vet (2014). Construct Validity of the Individual Work Performance Questionnaire

Lochhead, C., \& Stephens, A. (2004). Employee Retention,Labour Turnover \& Knowledge Transfer:Case Studies from the Canadian Plastics Sector. 100

Lock, E. A. (1976). The nature and causes of job satisfaction In M. D. Dunnette (Ed.), Handbook of industrial and organizational psychology (pp. 1293-1349) 
The Impact of an ODI on the Development of Leadership, Employee Motivation 40 and Employee Engagement towards Better Performance of Employees: A Case Study

Logan, S., \& Medford, E. (2011). Gender differences in the strength of association between motivation, competency beliefs and reading skill. Educational Research, 53, 85-94.

Lyons, A., \& DeFranco, J. (2010). A mixed-methods model for educational evaluation. The Humanistic Psychologist, 38(2), 146-158

Mahmoud Ali, Ra'Ed Masadeh, Bader Obeidat. (2018, May). The Effect of Employee Engagement on Organizational Performance via the Mediating Role of Job Satisfaction: The Case of IT Employees in Jordanian Banking Sector

Manzoor, Q.-A. (2012). Impact of employees motivation on organizational effectiveness. Business Management and Strategy, 3(1), 1.

Malek A. Tambi. (2018, January). The Impact of Human Resource Management Practices, Organizational Culture, Motivation and Knowledge Management on Job Performance with Leadership Style

McClelland, D.C. (1951). Measuring motivation in phantasy: the achievement motive.

Minbaeva, D. (2008). HRM practices affecting extrinsic and intrinsic motivation of knowledge receivers and their effect on intra- MNC knowledge transfer. International business review, 17(6), 703-713

Mitchell, H. (2002). Strategic worth of human resource: Driving organizational performance. 2002 Human resource conference. Universialia.

Mohammad Saeid Aarabi, Indra Devi Subramaniam, Abu Baker Almintisir, Abu Baker Akeel (2013). Relationship between Motivational Factors and Job Performance of Employees in Malaysian Service Industry

Morrison, E. W. (1994). Role definitions and organizational citizenship behavior: The importance of the employee's perspective. Academy of Management Journal, 37(6), $1543-1567$

Mrinal Kumar Dasgupta, IIFT. (2016). A Computational Framework for Assessing Impact of Port Efficiency on Maritime Logistics

Musmuliana, Y., \& Mustaffa, Y. (2012). Factors Influencing Organizational Performance in Metro Specialist Hospital, Sungai Petani, Kedah Darul Aman. Universiti Utara Malaysia.

Muogbo. (2013). The impact of employee motivation on organizational performance (a study of some selected firms in anambra state nigeria). The international journal of engineering and science, 2(7), 70-80.

Mwita, J. I. (2000), Performance management model: A system-based approach to system quality. The International Journal of Public Sector Management, Volume 13, No. 1, pp. 19-37.

Nansi Lidya Lolowang, Eka Afnan Troena, Atim Djazuli. (2019). The effect of leadership and organizational culture on employee performance that is educated by motivation (study on the implementation empowerment programs in Jayapura city). Problems and Perspectives in Management, 17(1), 268-277

Nick Nykodym, Clintin O.Longenecker, William N.Ruud. (2008). Improving Quality of Work Life with Transactional Analysis as an Intervention Change Strategy

$\mathrm{Ng}$ Kim Soon (2015). Employee Engagement and Job Satisfaction,

Ogbonna, E. \& Harris, L. C. (2000). Leadership style, organizational culture and performance. The International Journal of Human Resource Management, 766-788

O. M. Karatepe (2013). "High-performance work practices and hotel employee performance: the mediation of work engagement", International Journal of Hospitality Management, vol. 32, pp. 132-140.

Ömer Faruk Şimşek. (2015, December). Role of Leadership in Employees’ Work Engagement: Organizational Identification and Job Autonomy: Istanbul Rumeli University 
Parker, S., \& Skitmore, M. (2005). Project management turnover: causes and effects on project performance. International Journal of Project Management, 23(3), 205-214.

Parvesh Kumar Goyal. (2015). Motivation: Concept, Theories and practical implications: Assistant Professor, Department of Commerce, Dayanand Post Graduate College, Hisar, and Volume 6 Issue 8

Per Eisele. (2015, August). Team Performance Management: Linnaeus University

Perry, C. \& Zuber-Skerritt, O. (1992). Action Research in Graduate Management Programs, Higher Education, 23(2), 195-208.

Phillips, G. (2014). The Production-based PhD: An Action Research Model for Supervisors. Quality Assurance in Education, 22(4), 370-383.

P.L. Koopman, A.F.M. Wierdsma. (1998). Participative Management, Handbook of Work and Organizational Psychology, 2nd ed. Vol. III

Preko, A., \& Adjetey, J. (2013). A study on the concept of employee loyalty and engagement on the performance of sales executives of commercial banks in Ghana. International Journal Of Business Research And Management, 4(2), 51- 62.

Pruitt, D., \& Rubin, J. (1986). Social conflict: Escalation, stalemate, and settlement. New York, NY: Random House

QAISAR ABBAS and SARA YAQOOB. (2009). Effect of Leadership Development On Employee Performance in Pakistan: Pakistan Economic and Social Review Volume 47, No. 2, pp. 269-292

Qi L, Liu B, Wei X, Hu Y. (2019). Impact of inclusive leadership on employee innovative behavior: Perceived organizational support as a mediator. PLoS ONE 14(2): e0212091.

Rabindra Kumar Pradhan. (2016, December). Employee Performance at Workplace: Conceptual Model and Empirical Validation: Indian Institute of Technology Kharagpur and Lalatendu Kesari Jena Xavier Institute of Management, Bhubaneswar (XIMB)

Rahim, A., \& Bonoma, T. V. (1979). Managing organizational conflict: A model diagnosis and intervention. Psychological Reports, 44, 1323-1344.

Ram Bahadur Hamal. (2017, September). Participative Leadership Theory and its implication in Educational Administration and Management: Northeast Normal University,China,

Rebecca Mazin. (2017, August). Factors Affecting Employee Performance

Richard L.Draft, Dorothy Marcic. (2003). Understanding Management

Robert J House, Jane M.Hawell (1991). Personality and charismatic leadership

Robinson D, Perryman S, Hayday S (2004), The Drivers of Employee Engagement, Report 408, Institute for Employment Studies

Rowold, J. (2008). Multiple effect of Human Resource Development interventions. Journal of European Industrial Training (Emerald Publishing Group), Volume 32, No 1, pp. $32-44$.

Rotundo, M., \& Sackett, P. R. (2002). The relative importance of task, citizenship, and counterproductive performance to global ratings of job performance: A policy-capturing approach. Journal of Applied Psychology

Rousseau, V., \& Aubé, C. (2010). Team self-managing behaviors and team effectiveness: The moderating effect of task routineness. Group \& Organization Management, 35(6), $751-781$

Sagie A. (1996). Effects of Leader's communication style and participative goal setting on performance and attitudes

Sagie, A. (1997). Leader direction and employee participation in decision making: contradictory or compatible practices. Applied Psychology: An International Review, 46, $387-416$ 
The Impact of an ODI on the Development of Leadership, Employee Motivation 42 and Employee Engagement towards Better Performance of Employees: A Case Study

Saks AM (2006). Antecedents and consequences of employee engagement. J. Manage. Psychol. 21(7):600-619.

Sanford, N. (1970), Whatever happened to action research? Journal of Social Issues, 26(4), 3-23.

Sanhakot Vithayaporn. (2020). Employee Engagement and Innovative Work Behavior: A Case Study of Thai Airways International

Sekaran, U., \& Bougie, R. (2016). Research methods for business: a skill-building approach (7th ed.). Haddington: John Wiley \& Sons

Shaheen Ahmed, Abdul Rahman Bin Jaaffar. (2017). Employee job security and performance relationship in developing economy through employee engagement: Critical analysis with PLS-SEM

Sheri-Lynne, Leskiw and Parbudyal Singh (2007), Leadership development: learning from best practices. Leadership and Organization Development Journal, Volume 28, No. 5.

Shrijan Gyanwali \& John C. (2020). Influencing Factors of Organizational Performance in Nepal Airlines Corporation: Walsh, International Business Research; Vol.13, No.1,

S M Abu Nayem Sarker. (2017, May). Freight Forwarding Industry: Function, Economic Role and Future Market in Bangladesh: Taiyuan University of Technology

Solomon Akpoviroro Kowo, M .A Popoola, Olalekan.O, Akrinrinola, Salau Abdulazeez (2018). Moderating Influence of Organizational Reward System on Employee's Performance

S. Rana, A. Ardichvili, and O. Tkachenko (2014). "A Theoretical model of the antecedents and outcomes of employee engagement: Dubin's Method", Journal of Workplace Learning, vol. 26, issue 3/4, pp. 249-266.

Stringer, E. T. (2014). Action Research (4th Ed.). Thousand Oaks, CA: Sage Publications

Sundaray, B., 2011. Employee Engagement: A Driver of Organizational Effectiveness. European Journal of Business of Management, Volume Vol. 3 No. 8, pp. 53- 60.

Sungmin Hyun (2009). Re-examination of Herzberg's Two-Factor Theory of Motivation in the Korean Army Foodservice Operation

Sunyoung Park, Junghwan Kim, Jiwon Park, and Doo Hun Lim. (2018). Human Resource Development Review: Work Engagement in Nonprofit Organizations Vol.17

Tahir, N., Yousafzai, I. K., Jan, S., \& Hashim, M. (2014). The Impact of Training and Development on Employees Performance and Productivity A case study of United Bank Limited Peshawar City, KPK, Pakistan. International Journal of Academic Research in Business and Social Sciences, 4(4), 86.

Tareq M Zayed. (2015). The Role of Reading Motivation And Interest In Reading Engagement of Quranic Exegesis Readers

Teresa.M. Amabile, Michael Gerard Pratt. (2016). The dynamic componential model of creativity and innovation in organizations: Making progress, making meaning

Thomas, K. W., \& Kilmann, R. H. (1974). Thomas-Kilmann Conflict Mode Instrument. New York, NY: Xicom

TMariammal, A Amutha Jaisheeba, Rathinasamy Sornaraj. (2012). Occupation Influenced Physical Illness Observed Among the Teachers of Thoothukudi Town

Tobias Wiesenthal (2015). Innovation in the European transport sector

Torres, C. V. (2000). Leadership style norms among Americans and Brazilians: assessing differences using Jackson's return potential model. Dissertation Abstracts International: The Sciences and Engineering, 60, 4284

Wall, B., Solum, R.S. and Sobol, M.R. (1992). The Visionary Leader. Rocklin: Prima Publishing.

Warner, S., Herrmann, D.M. og Keary, D. (2001). In limbo on a new hire. HR magazine, 46 (11), 43-48. 
W.C.H Prentice (1961). Understanding Leadership

Weiner, B. (1985). An attributional theory of achievement motivation and emotion. Psychological Review

Weiner, B., \& Kukla, A. (1970). An attributional analysis of achievement motivation. Journal of Personality and Social Psychology

Wen Long Yue and Michael A P Taylor. (2005, January). The role of transportation in logistics chain: University of South Australia

West, G. (2005) Calibration of the SABR Model in Illiquid Markets. Applied Mathematical Finance, 12, 371-385.

W. H. Macey, and B. Schneider (2008). "The meaning of employee engagement", Industrial an Organizational Psychology, vol. 1, pp. 3-30

Wiklund, J. (1999). The sustainability of the entrepreneurial orientation -performance relationship. Entrepreneurship Theory and Practice, 24(1), 37-48.

Yang, C. (2006). The Effect of Leadership and Entrepreneurial Orientation of Small and Medium Enterprises on Business Performance in Taiwan (Doctoral dissertation). University of the Incarnate World.

Yukl, G. and P. Fu (1999), Determinants of delegation and consultations by managers. Journal of Organizational Behavior, Volume 20, No. 2, pp. 219-232

\section{Websites:}

Agility Emerging Markets Logistics Index Report. (2020). https://www.agility.com

Asia Economic Reports. (2019). https://www.adb.org

Chartered Institute of Personal and Development, 2006: https://www.cipd.co.uk/

Countries with the largest gross domestic product (GDP). (2019). https://www.statista.com

A.T Kearnery. (2019, June). Global and Asia economic profile.

https://www.prnewswire.com/news-releases/at-kearneys-2019-global-services-location-index-gsli-resonates-with-digital-change-300867002.html

International Monetary Fund. (2019, Oct). Global Economic of GDP. https://www.imf.org International Monetary Fund. (2019, April). World Economic Outlook Report. www.imf.org International Monetary Fund. (2019, Oct). ASEAN 2019 GDP Nominal and PPP GDP. https://www.imf.org

Investopedia. (2020, March). Global Economy Share on GDP. https://www.investopedia.com

Myanmar Border Export \& Import Report. (2019 2020). https://www.commerce.gov.mm/

The Gallup Organization (2006). https://www.gallup.com/ 